\title{
EVALUATION OF COMMERCIAL ROOT YIELD OF ARRACACHA (Arracacia xanthorrhiza Banc.) FROM BRAZILIAN GERMPLASM COLLECTION. Granate, Maria ${ }^{1}$; A. Y. Elsayed ${ }^{2,3}$; D. Silva ${ }^{2}$; P. M ${ }^{2}$; S. Emy ${ }^{1}$ ${ }^{1}$ EPAMIG-Minas Gerais Agric. Res. Corporation, Viçosa, MG., Brazil. ${ }^{2}$ Dept. of Plant Science, Univ. of Viçosa, MG, Brazil. \\ ${ }^{3}$ Veget. Res. Dept. Hort. Res. Inst., Agric. Res. Center, Giza, Egypt.
}

\begin{abstract}
Characterization and evaluation of germplasm collections is considered an achievement as important as maintaining the collection. The objective of this work was to evaluate quantitative yield traits of a collection of Brazilian arracacha to identify high yielding, early and duplicated accessions. All 67 accessions of the arracacha collection were planted in an experiment at the Horticultural Research Station of Public University of Viçosa, MG, Brazil. A randomized complete block design with two replications was used. Each plot contained 15 plants in three rows spaced one $\mathrm{m}$ apart and with $0.40 \mathrm{~m}$ between plants. After eight months of planting, only 38 accessions presented three or more competitive plants in both replications. Yield of four commercial class root (Extra A, Extra, Special and First) and total commercial root yield were evaluated in three competitive plants of each plot. Sixteen accessions did not produce Extra $A$ roots and eight accessions did not produced Extra roots. Accession BGH 6525 showed the highest total commercial root yield. Accession BGH 4551 showed highest Extra A root yield. Accession BGH 5747 showed highest Extra root yield.
\end{abstract}

Keywords: Arracacia xanthorrhiza, yield, germplasm, selection, root class.

\section{INTRODUCTION}

Arracacha (Arracacia xanthorrhiza Bancroft) belongs to family Apiaceae (Umbelliferae) which includes about 300 genera and 3000 species (Mathias 1971). The genus Arracacia includes about 30 species among them Arracacia xanthorrhiza is the only cultivated. This crop an asexually propagate and perennial plant (Blas et al. 2007). Although the diversity of genus Arracacia is particularly high in Mexico, Andean South America is considered the place of domestication of arracacha. Arracacha is produced mainly in four countries; Brazil, Colombia, Ecuador and Venezuela with total production area over 30 thousand hectares (Blas and Arbizu, 1999; Hermann, 2005). Edible part are tuberous roots which after cooking become an essentially starchy food with small portions of $\beta$-carotene, ascorbic acid and calcium and its utilization is intimately related to its high starch content, about 95\% (Hermann, 1997).

Three Andean horticultural forms could be found these forms were yellow-rooted, white-rooted and purplish-rooted (Hermann, 2005). Morphological variation in Brazilian cultivated gene pool of arracacha is small. Yellow-root cultivar is commercially grown in Brazil named 'Amarelo de Carandai' its accession number in germplasm collection is BGH 5746. It has intensive yellow root pigmentation and purplish petiole bases, yielding from 


\section{Granate, Maria}

$8.74 \mathrm{t} \mathrm{ha}^{-1}$ at 10 months after planting (Madeira et al., 2002) to $15.69 \mathrm{t} \mathrm{ha}^{-1}$ at eight months (Granate et al, 2004) or a bit more as in this experiment (Table 3 ). When compared with common commercial cultivars planted in Andean countries it has stronger flavor. Intensive yellow color and strong flavor are required by Brazilian fresh market and processing industry.

Usually arracacha remains in the field during 11 to 12 months and the main objective of breeding is to reduce this period. Commercial roots are classified in four classes (Extra A, Extra, Special and First). Prices range from one to four fold from the smallest (First) to the largest root class (Extra A) (CEASAMINAS, 2007). Accessions high yield with high percent of the two largest roots classes (Extra $A$ and Extra) after less than 10 months in the field needed to be identified.

The optimal utilization of germplasm collections depends on its informations from characterization and evaluation process. There are several arracacha collections at Ecuador, Peru, Colombia and Brazil. Most arracacha collections are well documented in terms of passport data but characterization and evaluation of arracacha germplasm collections is still uncompleted (Blas and Arbizu, 1999; Hermann, 1997; Rosso et al, 2004). Public University of Viçosa (UFV) began collecting arracacha germplasm in 1974 when the Horticulture Germplasm Bank (BGH) established arracacha field collection (Silva et al., 2001).

The aim of this investigation was to present first quantitative data of UFV - BGH arracacha collection: total commercial roots yield and four classes root yield of arracacha accessions in an attempt to identify high yielding accessions with high percent of the two Extra root yield classes after eight months in the field.

\section{MATERIALS AND METHODS}

At Viçosa, Minas Gerais State (MG), Brazil (latitude: 204'14" S, longitude: $42^{\circ} 52^{\prime} 55^{\prime \prime} \mathrm{E}$, altitude: $650 \mathrm{~m}$ " average temperature: $19^{\circ} \mathrm{C}$, average precipitation: $1.240 \mathrm{~mm}$, subtropical highland climate and cambic red-yellow podzolic terrace phase soil), were planted 67 accessions from BGH-UFV. Experiment was conducted at Horticultural Research Station of UFV, in the growing seasons of 2007and 2008. A randomized complete blocks design with 67 treatments and two replications and 15 plants per plot was applied. Total area was $1212 \mathrm{~m}^{2}$. Intra-row distance was $0.40 \mathrm{~m}$ and inter-row distance $1.00 \mathrm{~m}$. According to soil analysis result it was necessary to add calcium, N-P-K, potassium chloride and organic matter at following rates: 128 $\mathrm{Kg}$ of dolomite $(30 \% \mathrm{Ca}, 12.1 \% \mathrm{Mg}), 408 \mathrm{~g} \mathrm{~m}^{-2}$ of cattle manure both by throwing in all the field and $16 \mathrm{~g} \mathrm{~m}^{-1}$ of N-P-K $(0-25-15)$ in the row at planting time; at 90 days after planting were applied $2 \mathrm{~g} \mathrm{plant}^{-1}$ of potassium chloride fertilizer $(58 \% \mathrm{~K})$ in each plant. At planting time Nematicide "Furadan" was applied in the row.

Cormels were selected from healthy, ripe and productive plants, separated from crowns. Their apex and base were cut leaving four centimeters long propagules. Root productivity depends mainly on this 
correct cutting of cormels (Hermann, 1997; Sediyama and Casali, 1997). Since nematodes and soil diseases threaten root productivity a preventive treatment was applied to cormels. They were immersed for 5-10 mints in 10 $\%$ sodium hypochlorite solution and after let dry in shade for one day according to Sediyama and Casali (1997). Irrigation was made with conventional aspersion and manual weed control was done when necessary. In this study the harvest was at eight months after planting in order to identify early yielding accessions. In each plot were picked up three competitive plants randomly sampled. Only competitive plants should be picked up because plants not surrounded by other four plants produce much more and are not representative of commercial plantations. Roots were washed with tap water and dried in open air during one day and evaluated the day after.

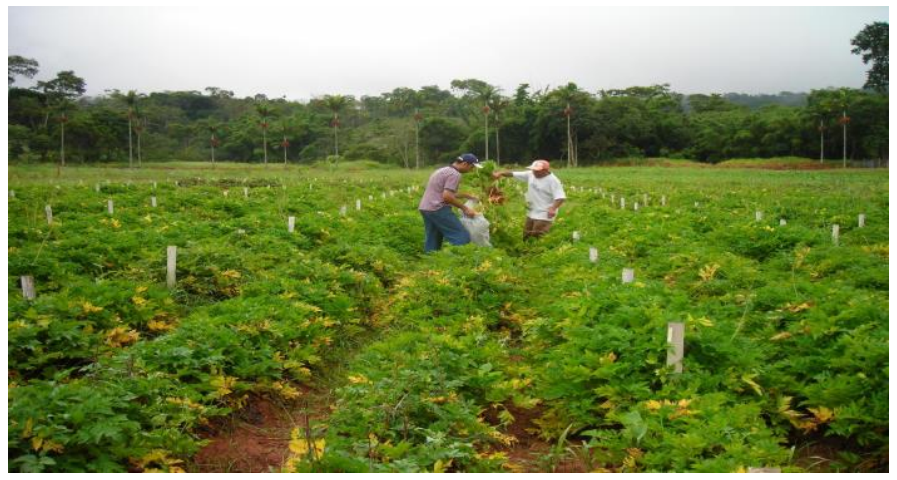

Fig 1. Experimental field with eight months old arracacha clones being picked up at random. Viçosa, January 2008.

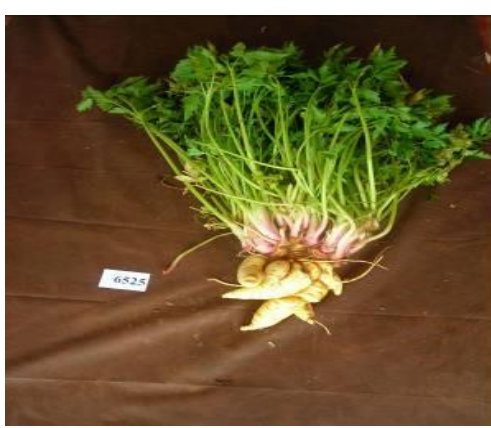

Fig 2. Arracacha accession BGH 6525 had highest total yield in this experiment.
( T

lal

to

ar

$\mathrm{cm}$ long and at least $3 \mathrm{~cm}$ largest diameter; First yield (FIR): yield of roots than $5 \mathrm{~cm}$ long and more than $1 \mathrm{~cm}$ of A): yield of roots 16 to $18 \mathrm{~cm}$ long and 4 I (EXT): yield of roots 13 to $16 \mathrm{~cm}$ long cial yield (ESP.): yield of roots 10 to 13

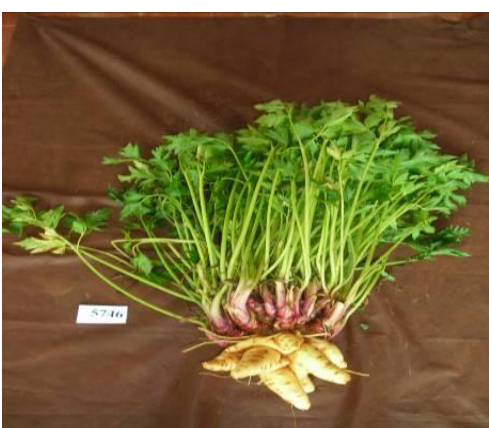

Fig 3. Arracacha accession BGH 5746 'Amarelo de
Carandaí is the most
commercially planted clone in Brazil.

e following traits: total commercial yield 
that did not belong to other classes. Percent of Extra A, Extra, Special and First roots in total commercial yield of each accession was computed. Analysis of variance and comparison of means using Tukey's test at $5 \%$ probability was applied. Computation utilized Software "GENES" program version 2007.6.1 developed at UFV (Cruz, 2001).

\section{RESULTS AND DISCUSSION}

There were losses of plants in emergency and during early growth which is a major constraint of this culture on which it is usual 10 to $15 \%$ emergency losses (Granate et al., 2003). Mean of percent of lost plants per plot was $22.67 \%$. This loss of stand higher than usual was supposed mainly due to weeds that had germinated at the same time of arracacha. At the harvest time the mean of plant number/plot was 11.60 but mean of number of competitive plant/plot was 5.00. From the 67 accessions planted only 38 accessions presented three or more competitive plants in both replications and only these 38 were evaluated. The other 29 accessions will be planted in another experiment with more plants in each plot. Neither nematode nor disease symptoms were observed on harvested roots.

The results of variance showed highly significant at $1 \%$ for traits total commercial roots yield of classes; Extra A roots yield, Special roots yield and First root yield and at 5\% probability level for Extra roots yield was only significant (Table 1) meaning that there are differences between accessions for these traits as expected.

Table 1: Summary of analysis of variance (mean squares) of total commercial roots and four-classes of arracacha yield (tha-1) evaluated after eight months of planting.

\begin{tabular}{|c|c|c|c|c|c|c|}
\hline \multirow{2}{*}{ S.V. } & \multirow{2}{*}{ D.F. } & \multicolumn{5}{|c|}{ Mean Squares } \\
\cline { 3 - 7 } & & TCY $^{\mathbf{1}}$ & EXT A & EXT & SPE & FIR \\
\hline Blocs & 1 & 94.63 & 4.70 & 6.48 & 6.55 & 6.03 \\
\hline Genotype & 37 & $124.11^{* *}$ & $6.64^{\star *}$ & $9.60^{*}$ & $17.61^{* *}$ & $23.07^{* *}$ \\
\hline Error & 37 & 16.86 & 2.08 & 5.44 & 4.80 & 4.81 \\
\hline
\end{tabular}

Environmental variance was lower than those genotype variance for all studied traits except Extra $A$ roots yield (Table 2) suggesting this trait is more influenced by environment than others. Coefficient of variance of Extra A roots yield and Extra roots yield are greater than those of others traits (Table 2) since 16 accessions did not give Extra A roots and 8 accessions did not produce Extra roots (Table 3 ).

Table 2: Parameters estimation of commercial roots yield and fourclasses of arracacha roots yield $\left(\right.$ tha $\left.^{-1}\right)$ evaluated after eight months of planting.

\begin{tabular}{|l|c|c|c|c|c|}
\hline \multirow{2}{*}{ Parameter $^{1}$} & \multicolumn{5}{c|}{ Trait } \\
\cline { 2 - 6 } & TCY & EXT A & EXT & SPE & FIR \\
\hline Phv & 62.06 & 3.318 & 4.80 & 8.81 & 11.53 \\
\hline Env & 8.43 & 1.038 & 2.72 & 2.40 & 2.40 \\
\hline Genv & 53.63 & 2.28 & 2.079 & 6.41 & 9.13 \\
\hline Coef & 51.42 & 103.69 & 49.05 & 64.39 & 51.09 \\
\hline Mean & 14.24 & 1.46 & 2.94 & 3.93 & 5.91 \\
\hline
\end{tabular}

1Phv: phenotypic variance; Env: Environmental variance; Genv: genotypic variance; Coef: genetic covariance 
Table 3: Total commercial yield and four classes roots yield means (Extra A, Extra, Special and First) evaluated in arracacha accessions harvested at eight months after planting.

\begin{tabular}{|c|c|c|c|c|c|c|c|c|c|}
\hline \multirow{3}{*}{$\begin{array}{l}\text { Clone } \\
\text { (BGH) }\end{array}$} & \multirow{2}{*}{\multicolumn{3}{|c|}{\begin{tabular}{|c|c} 
TCY $^{1}$ & Extra A \\
Yield & Yield \\
\end{tabular}}} & \multirow{2}{*}{\multicolumn{2}{|c|}{$\begin{array}{l}\text { Extra } \\
\text { Yield }\end{array}$}} & \multirow{2}{*}{\multicolumn{2}{|c|}{$\begin{array}{l}\text { Special } \\
\text { Yield }\end{array}$}} & \multirow{2}{*}{\multicolumn{2}{|c|}{$\begin{array}{l}\text { First } \\
\text { Yield }\end{array}$}} \\
\hline & & & & & & & & & \\
\hline & t ha $^{-1}$ & t ha $^{-1}$ & $\%^{2}$ & $\mathrm{tha}^{-1}$ & $\%^{2}$ & t ha $^{-1}$ & $\%^{2}$ & t ha $^{-1}$ & $\%^{2}$ \\
\hline 4551 & 20.63abcdefg & $5.83 a$ & 28.28 & $6.15^{\mathrm{a}}$ & 29.8 & 3.48abcd & 16.9 & 5.17abcdef & 25.1 \\
\hline 4552 & 7.73defghi & -- & -- & $1.96^{\mathrm{a}}$ & 25.3 & 2.56abcd & 33.2 & 3.21cdef & 41.5 \\
\hline 4553 & 19.13abcdefgh & $1.48 a$ & 7.73 & $3.36^{\mathrm{a}}$ & 17.5 & 6.83abcd & 35.7 & 7.46abcdef & 39.0 \\
\hline 4555 & 15.56abcdefghi & $4.05 a$ & 26.02 & $2.35^{\mathrm{a}}$ & 15.1 & 4.73abcd & 30.4 & 4.43cdef & 28.5 \\
\hline 4556 & 15.34abcdefghi & $0.83 a$ & 5.43 & $4.07^{\mathrm{a}}$ & 26.5 & $3.67 a b c d$ & 23.9 & 6.77abcdef & 44.1 \\
\hline 4557 & 21.73abcdef & $4.21 \mathrm{a}$ & 19.37 & $5.63^{a}$ & 25.9 & 5.65abcd & 26.0 & 6.25abcdef & 28.8 \\
\hline 4559 & 20.13abcdefgh & $5.48 a$ & 27.22 & $3.00 \mathrm{a}$ & 14.9 & 3.33abcd & 16.6 & 8.31abcdef & 41.3 \\
\hline 4560 & 21.58abcdef & $0.51 \mathrm{a}$ & 2.38 & $4.60^{\mathrm{a}}$ & 21.3 & 9.06abcd & 42.0 & 7.40abcdef & 34.3 \\
\hline 4579 & 13.79abcdefghi & $0.46 a$ & 3.32 & $1.23^{\mathrm{a}}$ & 8.9 & $3.10 a b c d$ & 22.5 & 9.00abcdef & 65.3 \\
\hline 4580 & $1.33 \mathrm{i}$ & -- & -- & -- & - & - & - & 1.33ef & 100.0 \\
\hline 5741 & 23.60abcd & $1.85 a$ & 7.86 & $3.81^{\mathrm{a}}$ & 16.2 & 3.61abcd & 15.3 & $14.32^{\mathrm{a}}$ & 60.7 \\
\hline 5742 & 15.27abcdefghi & $1.75 a$ & 11.46 & $1.87^{\underline{a}}$ & 12.2 & 2.89abcd & 18.9 & 8.77abcdef & 57.4 \\
\hline 5746 & 16.15abcdefghi & 1.00a & 6.19 & $4.09^{a}$ & 25.3 & 3.92abcd & 24.2 & 7.15abcdef & 44.2 \\
\hline 5747 & 22.54abcde & $1.79 a$ & 7.95 & $6.39^{\mathrm{a}}$ & 28.4 & 5.94abcd & 26.3 & 8.42abcdef & 37.3 \\
\hline 6311 & 19.51abcdefgh & -- & -- & $1.61^{\mathrm{a}}$ & 8.3 & 10.73ab & 55.0 & 7.17abcdef & 36.7 \\
\hline 6403 & -- & -- & -- & -- & -- & -- & -- & $\begin{array}{ll}-- \\
\end{array}$ & -- \\
\hline 6411 & 6.81defghi & -- & -- & -- & -- & $1.83 \mathrm{bcd}$ & 26.9 & 4.98bcdef & 73.1 \\
\hline 6417 & 20.62abcdefg & $5.75 a$ & 27.86 & $6.02^{\mathrm{a}}$ & 29.2 & $2.58 a b c d$ & 12.5 & 6.27abcdef & 30.4 \\
\hline 6423 & 17.05abcdefghi & $4.00 a$ & 23.46 & $3.35^{\mathrm{a}}$ & 19.7 & 3.79abcd & 22.2 & 5.91abcdef & 34.7 \\
\hline 6429 & $5.27 f g h i$ & -- & -- & $2.94^{\mathrm{a}}$ & 55.7 & $0.67 \mathrm{~cd}$ & 12.6 & 1.67ef & 31.6 \\
\hline 6436 & 9.79bcdefghi & -- & -- & $1.81^{\mathrm{a}}$ & 18.5 & $1.98 \mathrm{bcd}$ & 20.2 & 6abcdef & 61.3 \\
\hline 6445 & 9.35cdefghi & $1.65 a$ & 17.60 & $2.36^{\mathrm{a}}$ & 25.2 & $1.71 \mathrm{bcd}$ & 18.3 & $3.65 \mathrm{cdef}$ & 39.0 \\
\hline 6458 & 4.14ghi & -- & -- & -- & 0.0 & $0.77 \mathrm{~cd}$ & 18.6 & 3.37cdef & 81.4 \\
\hline 6467 & 17.19abcdefghi & $1.17 a$ & 6.79 & $5.85^{\mathrm{a}}$ & 34.1 & 5.40abcd & 31.4 & 4.77bcdef & 27.8 \\
\hline 6480 & 4.23ghi & -- & -- & -- & 0.0 & 2.81abcd & 66.5 & 1.42ef & 33.5 \\
\hline 6490 & 13.98abcdefghi & 3.83a & 27.43 & $1.82^{\mathrm{a}}$ & 13.0 & 3.56abcd & 25.5 & 4.76cdef & 34.1 \\
\hline 6494 & 7.40defghi & -- & -- & $1.35^{\mathrm{a}}$ & 18.3 & 3.54Abcd & 47.9 & $2.5 \mathrm{cdef}$ & 33.8 \\
\hline 6507 & 11.21abcdefghi & -- & -- & $5.58^{a}$ & 49.8 & 3.61abcd & 32.2 & 2.02def & 18.0 \\
\hline 6518 & $5.13 f g h i$ & -- & -- & -- & 0.0 & $1.35 \mathrm{~cd}$ & 26.3 & 3.78cdef & 73.7 \\
\hline 6525 & $28.38 a$ & $3.46 \mathrm{a}$ & 12.20 & $4.6^{\underline{a}}$ & 16.2 & $6.35 \mathrm{bcd}$ & 22.4 & 13.96ab & 49.2 \\
\hline 6529 & 2.96hi & -- & -- & -- & -- & -- & -- & 2.96cdef & 100.0 \\
\hline 6538 & 6.05efghi & $0.75 a$ & 12.39 & $2.06^{\mathrm{a}}$ & 34.0 & -- & -- & $3.25 \mathrm{cdef}$ & 53.6 \\
\hline 7605 & 4.16ghi & -- & -- & -- & -- & $1.83 \mathrm{bcd}$ & 44.0 & 2.33cdef & 56.0 \\
\hline 7606 & 17.05abcdefghi & $1.50 \mathrm{a}$ & 8.82 & $2.13^{\underline{a}}$ & 12.5 & 2.38abcd & 13.9 & 11.04abcd & 64.7 \\
\hline 7607 & 22.89abcde & $2.54 a$ & 11.10 & $3.78^{a}$ & 16.5 & 9.69abc & 42.3 & 6.88abcdef & 30.0 \\
\hline 7610 & 21.88abcdef & -- & -- & $7.27^{\underline{a}}$ & 33.2 & 7.69abcd & 35.1 & 6.92abcdef & 31.6 \\
\hline 7609 & 24.95abc & $1.44 a$ & 5.76 & $5.07^{\mathrm{a}}$ & 20.3 & 6.93abcd & 27.8 & 11.5abc & 46.1 \\
\hline 7608 & $26.65 a b$ & -- & -- & $5.56^{\mathrm{a}}$ & 20.9 & $11.42 a$ & 42.8 & 9.67abcde & 36.3 \\
\hline
\end{tabular}

TCY: root length 5 to $18 \mathrm{~cm}$ or more and 1 to $5 \mathrm{~cm}$ or more in diameter; EXT A: root length 16 to $18 \mathrm{~cm}$ and 4 to $5 \mathrm{~cm}$ in diameter; EXT root length of 13 to $16 \mathrm{~cm}$ and 3 to $4 \mathrm{~cm}$ in diameter; SPE: root length 10 to $13 \mathrm{~cm}$ and at least $3 \mathrm{~cm}$ in diameter; First: root length of 10 to $15 \mathrm{~cm}$ or more than $18 \mathrm{~cm}$ and 1 to $3 \mathrm{~cm}$ in diameter or more than $5 \mathrm{~cm}$ in diameter. $2 \%$ : of total commercial yield of each accession.

Total commercial roots yield mean of all accessions (Table 2) was greater than that obtained by Madeira et al. (2002) at 10 months after planting for accession BGH 5746 and for its other 17 high yielding accessions experiment mean of $9.82 \mathrm{t} \mathrm{ha}^{-1}$. This was an unexpected result since accessions in this experiment are a mixture of commercial and non- 


\section{Granate, Maria}

commercial accessions. This experiment mean was lower than Granate et al. (2004) 29 high yielding accessions experiment mean of $17.88 \mathrm{t} \mathrm{ha}^{-1}$. Clone BGH 6403 can be eliminated from germplasm bank because it did not produce commercial roots in any plant of both replications.

Twenty four accessions cleared in significant different in total commercial yield according to Tukey test at $5 \%$ probability (Table 3 ). Their total commercial yield was greater than $10.95 \mathrm{t} \mathrm{ha}^{-1}$, the Minas Gerais State mean for 12 months in the field (Torres, 1997). Six accessions yielded 22.00 tha ${ }^{-1}$ or over which is considered very high yield specially because it was obtained four months earlier than usual. Accession BGH 6525 was the more productive. This accession was originated at Viçosa from seed which is a very rare achievement and is a new genotype (Sediyama, 1988). However its percent of Extra $A$ and Extra roots is not one of the highest (Table 3). The 22 accessions that produced Extra A roots do not differ according to Tukey test (Table 3 ) and five of them reached more than $25 \%$ of Extra A roots. The greatest Extra A yielding clone is inferior to Madeira et al. (2002) bests but those were picked up at 10 months after planting. Thirty accessions produced Extra roots and from these eight presented Extra root yield above $5.50 \mathrm{t} \mathrm{ha}^{-1}$ overgrowing Madeira et al. (2002) highest Extra root yield of $5.11 \mathrm{t} \mathrm{ha}^{-1}$. Any accession showed the three desired characteristics of high total commercial yield and high Extra A and Extra root percent. Accession BGH 5747 was considered the best because its total commercial yield was more than twice Minas Gerais mean and its Extra root yield is almost one third of total commercial yield. It may be recommended as a new commercial cultivar after experiments in other regions of the State.

\section{Acknowledements}

This research was supported by a grant from FAPEMIG - Fundação de Auxílio à Pesquisa de Minas Gerais (Minas Gerais Foundation for Research Support).

\section{REFERENCES}

Blas, R. and Arbizu, C. 1999. Caracterización morfológica de la arracacha (Arracacia xanthorrhiza). In: Raíces y tuberculos andinos. Avances de Investigación. Fairlie I., Morales B., Holle M. (eds.). p. 111-128. Lima. Centro International de la Papa y Consorcio para el Desarollo Sostenible de la Ecorregión Andina.

Blas, R.; Hermann, M.; Baudoin, J.-P. 2007. Analysis of the geographic distribution and relationships among Peruvian wild species of Arracacia. Genet Resour CropEvol.

CEASAMINAS-Centrais de Abastecimento de Minas Gerais S/A. 2007. http://minas.ceasa.mg.gov.br/internet/PrecosInterior/PrecosInterior.php

Cruz, C. D. 2001. Programa Genes Versão Windows Aplicativo Computacional em Genética e Estatística. Viçosa. Editora UFV. 648 p.

Granate, M. J.; Oliveira, L. R.; Sediyama, M. A. N.; Cruz, C. D. 2003. Estudo da pós-emergência de clones de batata-baroa. II Brazilian Congress for Plant Breeding. CD-ROM, Paper TO19.pdf. 6 p. Porto Seguro, Brazil, 23-26 April. 
Granate, M. J.; Sediyama, M. A. N.; Oliveira, L. R.; Cruz, C. D.; Puiatti, M. 2004. Clonal selection in arracacha breeding. Crop Breeding and Applied Biotechnology 4:105-110.

Hermann, M. 1997. Arracacha (Arracacia xanthorrhiza Bancroft). In: Hermann, $M$ and Heller, J. (ed.). Andean roots and tubers: Ahipa, arracacha, maca and yacon. Promoting the conservation and use of underutilized and neglected crops. 21. Institute of Plant Genetics and Crop Plant Research, Gatersleben/International Plant Genetics Resources Institute, Rome Italy, p. 75-172. 256p.

Hermann, M. 2005. The arracacha (Arracacia xanthorrhiza Bancroft). International Potato Center (CIP), Lima 100, La Molina, Peru.

Madeira, N. R.; Santos, F. F.; Souza, R. J. 2002. Desempenho de clones de mandioquinha-salsa na região de Lavras - MG. Ciência e Agrotecnologia, 26:711-718.

Mathias, M.E. 1971. Systematic survey of New World Umbelliferae. In The Biology and Chemistry of the Umbelliferae. Suppl. 1 to Botan. J. Linnean Soc. 64:13-30.

Rosso, C. A, Medina C. I., Lobo M. 2004. Morphologic characterization and agronomic evaluation of a Colombian collection of arracacha (Arracacia xanthorrhiza Bancroft). Plant Genetics Resources Newsletter, n.132, p.22-29.

Sediyama, M. A. N. and Casali, V. W. D. 1997. Propagação vegetativa da mandioquinha-salsa. Informe Agropecuário 190: 24-27.

Silva, D. J. H., Moura, M. C. C. L., Casali, V. W. D. 2001. Recursos genéticos do banco de germoplasma de hortaliças da UFV: histórico e expedições de coleta. Horticultura Brasileira 19:108-114.

Torres, G. 1997. Mandioquinha-salsa: alimento energético. Informe Agropecuário, 190:3.

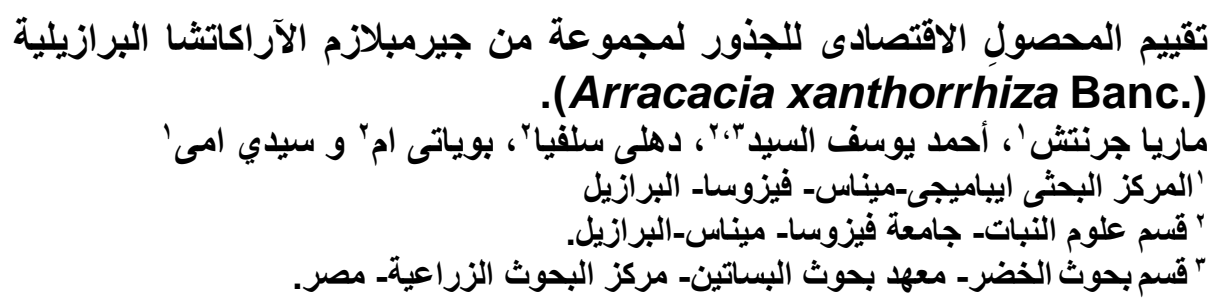
.(Arracacia xanthorrhiza Banc.)

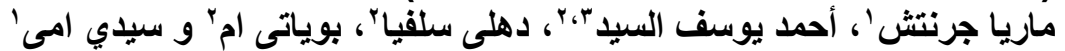

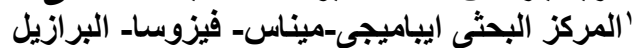

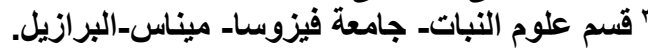

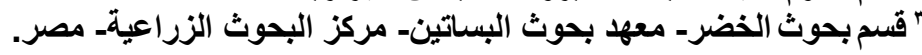

يُعتَبر توصييف وتقييم مجموعاتِ الجيرمبلازم من الامورالضرورية لإيجاد توازنٍ أفضل بين

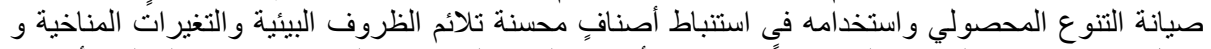

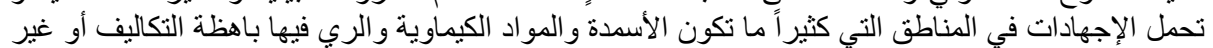

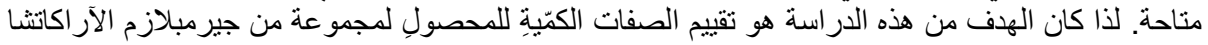

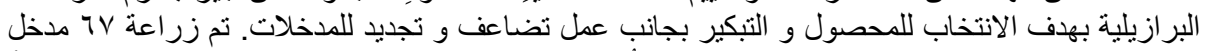

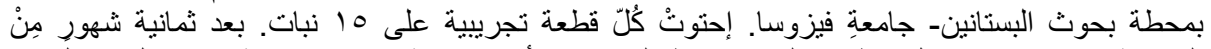

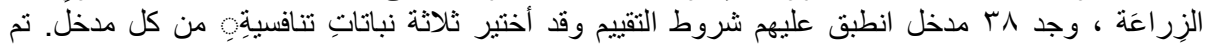

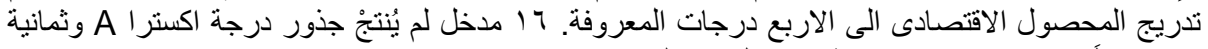

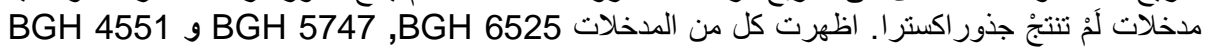
اعلى محصول كليّ , اكسترا A و و اكستر ا على الترتيب. 